\title{
IAMJ
}

INTERNATIONAL

AYURVEDIC

MEDICAL JOURNAL

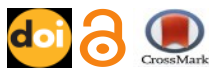

Review Article

ISSN: 23205091

Impact Factor: 5.344

\section{A CONCEPTUAL STUDY TO UNDERSTAND THE PHYSIOLOGICAL PERSPECTIVE OF SHUKRA DHATU}

\author{
Resmy Raj. A ${ }^{1}$, Chitra. M. Gawande ${ }^{2}$ \\ ${ }^{1}$ Assistant Professor, Dept of Kriya Shareera, SDM Institute of Ayurveda and Hospital, Bangalore, Karnataka, \\ India \\ ${ }^{2}$ Professor, Dept of Kriya Shareera, SDM Institute of Ayurveda and Hospital, Bangalore, Karnataka, India
}

Email: resmyrajayu12323@gmail.com

https://doi.org/10.46607/iamj0807182020

(Published online: July 2020)

Open Access

(C) International Ayurvedic Medical Journal, India 2020

Article Received: 19/06/2020 - Peer Reviewed: 21/06/2020 - Accepted for Publication: 01/07/2020

Check for updates

\begin{abstract}
Ayurveda is the 'Science of Life' and its aim is to maintain healthy status of healthy living being, i.e. prevention and treatment of disease. As per Ayurvedic Science, Purusha consists of three Dosha, seven Dhatu and three Mala which are the primary basis of living body. Dhatu are those which give support and strength to the body. Shukra is the seventh Dhatu, which is responsible for all systemic body activities including metabolic functions and performs specific functions of reproduction. According to Acharya Vagbhata and Charaka, Shukra is one which responsible for the process of Garbhotpadana (reproduction). According to Susrutha, Shukra provides courage, nourishment, happiness, strength and production of offspring. Main objective of this study is to review the conceptual facts of Shukra Dhatu from different classical Ayurveda texts and to analyse the physiological perspective about the same. In this article, the classical references related to Shukra Dhatu is collected and tried to correlate the concept with modern physiological entities. From the available references in the Samhitas, Shukra Dhatu can be better co related to sperm along with semen, sex hormones (oestrogen, androgen etc.), and sex chromosome.
\end{abstract}

Keywords: Shukra Dhatu, Sthree Shukra, semen, sex chromosome, sex hormone, Shukradhara kala 


\section{INTRODUCTION}

Ayurveda is the 'Science of Life' and its aim is to maintain healthy status of healthy living being, i.e. prevention and treatment of disease. As per Ayurvedic Science, Purusha consists of three Dosha, seven Dhatu and three Mala which are the primary basis of living body ${ }^{1}$. Dosha, Dhatu and Mala are considered as roots of living body because as roots maintains the life of plant, these three factors also sustains the life of human. Among all seven Dhatus, Shukra Dhatu is considered as the best ${ }^{2}$. Shukra Dhatu is the one which is highly involved in reproductive functions of the body (Garbhotpadana). Every cell in the body is involved in reproduction by mitosis and meiosis; hence the presence of Shukra Dhatu throughout the body gets identified. Main objective of this study is to review the conceptual facts of Shukra Dhatu from different classical Ayurveda texts and to analyse the physiological perspective about the same.

\section{Aim and Objectives}

To compile description of Shukra Dhatu as explained in different classical Ayurveda texts.

To review the concept of Shukra Dhatu with specific reference to sex hormones, semen, sex chromosome.

\section{Materials and Methods}

Literary materials were collected from all Ayurveda classical texts (Charaka Samhita, Sushruta Samhita Astanga Hridaya, Astanga Sangraha) and commentaries. Modern books of physiology were also reviewed to collect the data. Classical data collected were compared and analysed with modern scientific knowledge. The term Shukra is derived from the Sanskrit root word Shucha+Klede, which means purity ${ }^{3}$. The term has other meanings like bright, resplendent, and white. Shukra Dhatu is the seventh Dhatu and Teja, Reta, Veeryam, are synonyms of Shukra Dhatu ${ }^{4}$. Shukra is Soumya which is derived from Jalamahabhuta. It is the product of four proto elements Vayu, Agni, Aapa and Prithvi with all six rasa ${ }^{5}$.

\section{Functions of Shukra Dhatu}

Shukra is a factor which is responsible for Garbhotpaadana (Production of off springs). It gives Dhairyam (Courage), Chyavanam (ejaculation), Preeti (attraction or love towards opposite sex), Harsham, (pleasure, sexual excitement), Dehabalam (energetic, enthusiastic and nourishing property) also ${ }^{6}$. Functions of Shukra Dhatu can be categorized as Sarvadaihika karma (systemic function) and Garbhotpadana karma (reproductive functions) mainly. Sarvadaihika karma of Shukra Dhatu includes Dhairyam and Dehabalam. Dhairya is the control over mind, by which one does the good and avoids the bad. By this quality, one can face any difficulties without much anxiety. Acharya Dalhana describes it as the capacity to fight against any condition ${ }^{7}$. Dehabalam includes both Deha Upachaya (body nourishment) as well as Utsaha (enthusiasm) ${ }^{8}$. Upachaya is the physical nourishment which imparts Bala to the individual. Whereas Utsaha is the physical and mental enthusiasm to perform any activity.

Garbhotpadana and Maithunagata karma includes Preeti, Harsham,Chyavanam and beejartham. The word meaning of Chyavana is "to secrete". According to Acharya Dalhana, Chyavana is the ejaculation of semen ${ }^{9}$. Harsha in relation to sexual act may be understood as desire or exhilaration (Utkantha $\mathrm{Ja}$ nanam $\left.^{10}\right) \cdot$ Preeti is the love and affection towards opposite $\operatorname{sex}^{11}$. Since cellular division and proliferation take place in entire living body, the Garbhotpadana karma of Shukra Dhatu can be included in both Sarvadaihika and Beejarthagata karma. All these functions intimate that Shukra Dhatu is not only responsible for production of progeny, but also involved in other systemic bodily functions.

\section{Location of Shukra Dhatu}

Like every other Dhatu, it is also located in the entire body. Various Acharyas have quoted different description about Shukra Dhatu Sthana as: As fragrance is not manifested in a flower bud, but the same gets exhibited once it blossoms similarly is the Shukra. In childhood Shukra is present in body in Avyaktaroopa, as puberty is achieved, functions of Shukra starts manifesting ${ }^{12}$. Shukra is pervaded all over the body like juice in sugarcane, ghee in curd and oil in sesame seed $^{13}$. Location of Shukradhara kala is also throughout the body ${ }^{14}$. The Moola sthana (source of origin) of Shukravahasrothas are testes, penis, breast and 
majja ${ }^{15,16,17}$. These all references as cited above reveal that Shukra Dhatu is present generally in each and every cell and specifically in reproductive organs of the body.

\section{Shukra Dhatu, Shukravahasrotas in modern view- point}

Based on functions, Shukra Dhatu can be primarily understood as sex hormones and semen with sperm. Action of sex hormones can be counted for all the above metabolic functions of Shukra Dhatu. Beejarthagata karma may specify semen along with sperm and it is mainly involved in reproduction.

Shukravaha Srotas can be understood as all micro, macro channels responsible for production, transformation and transportation of sperm. Hypothalamo hypophyseal gonadal axis involved in sex hormone production can also be taken here. Hypothalamic hypophyseal gonadal axis (HPG) directs secretion of FSH and LH. Both of these hormones are very much essential for production of sex hormone and gametogenesis. In male, Shukravaha Srotas correlation might be HPG axis and semen producing, transforming and transporting pathway. In female it might be the hypothalamo hypophyseal gonadal axis only, because artavavahasrotas are directed for the transformation and transportation of ovum.

\section{Formation of Shukra Dhatu and Shukradhatvagni}

Shukra Dhatu is formed from Snehamsha of majja $D_{\text {Dhatu }}{ }^{18,19}$. One month is required for conversion of Ahara Rasa into Shukra Dhatu ${ }^{20}$. By the action of Majja Dhatu Agni on Majjasadharmiamsa; Prasada and Kittabhaga get formed. Prasadabhaga formed as Sthoola and Sookshmabhaga. Sthoolabhaga is Majja Dhatu and Sookshmabhaga is Majjaupadhatu and Shukrasadharmiamsa. Shukrasadharmiamsa is again acted upon by Shukradhatvagni and sthayi Shukra Dhatu gets formed. The unctuous portion of Majja which oozes out from Asthi also forms Shukra Dhatu ${ }^{21}$.

Mastishka (brain) is also made up of Majja Dhatu on$1 y^{22,23}$. So, the hypothalamo hypophyseal gonadal/testicular axis and its role in regulation of spermatogenesis can be previewed, if Mastishkamajja Dhatu is considered in Shukra Dhatu Utpatti. Gonadotropin releasing hormone ( $\mathrm{GnRh})$ from hypothalamus initiates secretion of Follicular stimulating hormone (FSH) and Luteinizing hormone (LH) from pituitary. FSH helps to increase LH receptors on Leydig cells which are the sites of formation of testosterone. $\mathrm{LH}$ helps to increase secretion of testosterone which in turn promotes spermatogenesis. FSH can initiate the proliferative stage of spermatogenesis too ${ }^{24}$.Hence Majja as Masthishka Majja involvement in Shukra Dhatu utpatti gets clarified.

Haematopoiesis from uncommitted pluripotent haemopoietc stem cells takes place in bone marrow also could prove the importance of Majja Dhatu. Here also production of new cells (Beejartha karma of Shukra Dhatu) is happening ${ }^{25}$.If sex steroids including androgen are taken in the preview of Shukra Dhatu, it is originated from cholesterol. Cholesterol undergoes conversion to pregnenolone which converts into progesterone and 17 alphas hydroxy pregnenolone. Progesterone ultimately turns into androstenedione. 17alpha hydroxy pregnenolone converts into DHEA. DHEA is ultimately converted to form androstenedione and eventually forms testosterone ${ }^{26}$. The importance of Snehamsa in production of Shukra Dhatu proved from the evidence that sex hormones too produced from cholestrol ${ }^{27}$.

Shukradhatvagni which helps in the formation of Shukra Dhatu can be understood as CYP 11 A 1 enzymes, 17 alpha hydroxylase,3 beta HSD 2,17 20 alpha hydroxylase which are involved in the formation of sex hormones from cholesterol. Testosterone exerts its action in tissues as DHT.5 alpha reductase (secreted from Sertoli cells) which takes part in the formation of DHT can also be included in the umbrella of Shukra dhatvagni ${ }^{28}$. Oestradiol and oestrone are originated from testosterone by the action of aromatase enzyme from sertoli cells. GnRh, FSH, LH hormones which are involved in spermatogenesis and oogenesis also can be taken as Shukradhatvagni. Shukradhatvagni might comprise all the hormones and enzymes which are involved in spermatogenesis and sex hormones production.

Existence of Shukra in childhood and Shukra abhivyakti 
According to Caraka and Susrutha, even though Shukra Dhatu is seen from the childhood, but its action is more exhibited during puberty (Vaya Parinamat ${ }^{29,30}$. The spermatogenesis starts from the seventh week of intra uterine life. Amount of testosterone increases during the first three months after the birth and then fall by one year and remain low until the onset of puberty. Oogenesis takes place before birth, but the ovum is still in primary oocyte stage during puberty and further progress happens during ovulation only. Hence the importance of Vaya Parinamat may be understood as the onset of puberty. Developments of axillary and pubic hair during puberty (Romaraji Udbhavam) are also due to the effect of sex hormones. Till puberty, a slightest secretion of sex steroid hormone produces a strong negative inhibitory feedback to $\mathrm{GnRh}$ secretion and to testosterone.

\section{Shukra Dhatu in female}

As per Susrutha and Caraka, Sthree Shukra is produced during the sexual intercourse and it is not responsible for the production of offspring ${ }^{31,32}$. Bartholin secretion at the time of copulation can be taken as Sthree Shukra. And the same secretion is not garbhaotpadana samartha (involved in production of offspring). All the secondary sexual characters in female like development of pubic and axillary hairs etc. are due to the presence of sex hormones ${ }^{33}$. So, Shukrathe seventh Dhatu which can be viewed as sex hormones which is helpful for the systemic body functions and takes part in the development of secondary sexual characters, and other glandular secretions like Bartholin secretion which are related to reproduction in females. In another context, it is said that predominance of Shukra can produce male progeny and predominance of artava results in female offspring ${ }^{34}$ which suggest that these two entities can also be understood as X, Y sex chromosomes. So, it can be concluded that artava may be a factor which is responsible for ovulation, menstruation and gender determination. Shukra might be the sex hormones involved in the formation of secondary sexual characters and the Bartholin secretions.

\section{Existence of Shukra in old age}

Function of Shukra Dhatu is progressively decreasing during oldage ${ }^{35}$. Serum free and total testosterone also progressively decreasing after 70-80 years of age ${ }^{36}$.

\section{Shudha Shukra lakshana}

As per various references, pure Shukra has the characteristic features like white crystalline colour, heavy, sweet taste, dense and has the consistency of ghee, honey and oil ${ }^{37,38}$. Madhura rasa of shudha Shukra is due to the fructose content in semen, from seminal vesicle and Ghruta makshika tailabham (consistency) might be the weak coagulum formation and its secondary liquefaction during semen ejaculation ${ }^{39}$. Sphatikabha (sankhabham, shuklam) indicates the colour of semen which is milky white due to prostatic secretion $^{40} . \mathrm{pH}$ of the semen is 7.3-7.4 which is referred by the term Avidahi i.e., not causing burning sensation indicating neither acidic nor highly alkaline. Gurutvam and bahalam (heaviness) indicates the specific gravity (1.028) imparted by seminal contents Bahu indicates the sperm content (50-200 milliom/cu $\mathrm{mm}){ }^{41}$. All the above properties of shudha Shukra well match to the physical properties of seminal fluid only.

\section{Shukra Dhatu sara purusha lakshana}

Shukra Dhatu sara purusha lakshana includes gentle behaviour, good looking, charming, eyes with milky appearance, even and compact teeth, compact bones, charming, soothing voice and radiant complexion etc $^{42}$.

Excess testosterone provides aggressiveness (Asoumyatva). It is proved that androgen deficiency can cause meibomian gland dysfunction and dry eyes. The sex steroid hormonal status plays a role in the homeostasis and function of ocular surface, accomplished by estrogenic and androgenic receptors located on corneal, conjunctival epithelia and in Meibomian gland The ocular surface dysfunction leads to unstable preocular tear film which produce dry eye $^{43}$ (Ksheerapoornalochana). Testosterone also provides the attraction towards opposite sex (Sthreepriyopabhoga). Radiant appearance (Bhrajishnutha) in Shukra Dhatu sara purusha may be produced due to the vasodilation produced by sex hormones especially 
estrogen. Testosterone can influence the bone-mineral metabolism (Samasamhata shikhara dasana, Samasamhataasthi) and also in deposition of subcutaneous fat (Mahasphik). Testosterone can cause the hypertrophy of laryngeal muscles and thickening of vocal cord also (Prasannasnigdhaswara). Testosterone can increase the quantity of melanin pigment in skin and also increases the thickness and ruggedness of skin.

\section{DISCUSSION}

From all the above classical references like formation, function and Shukra Dhatu sarata, the particular Dhatu can be better correlated with sex hormones. Following table illustrates the same.

Table 1: Shukra Dhatu comparison with sex hormone

\begin{tabular}{|c|c|c|c|}
\hline \multicolumn{4}{|c|}{ Shukra Dhatu Vs Sex hormones ${ }^{44}$} \\
\hline \multicolumn{2}{|l|}{ Shukra Dhatu } & \multirow[b]{2}{*}{$\begin{array}{l}\text { Testosterone } \\
\text { Action seen throughout the entire } \\
\text { body. } \\
\text { Secreted from Leydig cells in testis } \\
\text { and from adrenal cortex. }\end{array}$} & \multirow{2}{*}{$\begin{array}{l}\text { Estrogen } \\
\text { Throughout the entire body. } \\
\text { Secreted from granulose cells of } \\
\text { ovarian follicle from adrenal cortex }\end{array}$} \\
\hline $\begin{array}{l}\text { Location and } \\
\text { action }\end{array}$ & $\begin{array}{l}\text { Throughout the entire } \\
\text { body } \\
\text { (Sarvasareeravyapi) }\end{array}$ & & \\
\hline $\begin{array}{l}\text { Shukravaha } \\
\text { sroto moolam } \\
\text { (Source of } \\
\text { Origin) }\end{array}$ & $\begin{array}{l}\text { Testes, penis, breast } \\
\text { (Reproductive activity) }\end{array}$ & $\begin{array}{l}\text { Cause pubertal enlargement of tes- } \\
\text { tes, penis and scrotum, Descent of } \\
\text { testis, Growth of accessory sex or- } \\
\text { gans like seminal vesicle and pros- } \\
\text { tate }\end{array}$ & $\begin{array}{l}\text { Development of stromal tissues of } \\
\text { breasts, Growth of an extensive duc- } \\
\text { tile system in breast. Deposition of } \\
\text { fat in the ductile system. }\end{array}$ \\
\hline Formation & Snehamsa of Majja & $\begin{array}{l}\text { Cholesterol ultimately converts to } \\
\text { form androgen } \\
\text { Hypothalamo pit gonadal axis helps } \\
\text { in the formation of FSH, LH Which } \\
\text { are necessary for hormone produc- } \\
\text { tion } \\
\text { (involvement of Mastaka Majja) }\end{array}$ & $\begin{array}{l}\text { Cholesterol ultimately converts to } \\
\text { form oestrogen } \\
\text { Hypothalamo pit gonadal axis helps } \\
\text { in the formation of FSH, LH Which } \\
\text { are necessary for hormone produc- } \\
\text { tion } \\
\text { (involvement of Mastaka majja) }\end{array}$ \\
\hline $\begin{array}{l}\text { Time of } \\
\text { manifesta- } \\
\text { tion of action }\end{array}$ & Balanam vayaparinamat & $\begin{array}{l}\text { At puberty hypothalamic cells be- } \\
\text { come more mature and sensitivity } \\
\text { for circulating sex hormone de- } \\
\text { creases so much. So, there is a pul- } \\
\text { satile release of GnRh from hypo- } \\
\text { thalamus favours FSH, LH release } \\
\text { from pituitary too. } \\
\text { Spermatogenesis starts in puberty. } \\
\text { Testosterone amount starts rising. }\end{array}$ & $\begin{array}{l}\text { At puberty hypothalamic cells be- } \\
\text { come more mature and sensitivity for } \\
\text { circulating sex hormone decreases so } \\
\text { much. So, there is a pulsatile release } \\
\text { of GnRh from hypothalamus favours } \\
\text { FSH, LH release from pituitary too. } \\
\text { Further development of primary oo- } \\
\text { cyte to secondary oocyte takes place }\end{array}$ \\
\hline $\begin{array}{l}\text { Influence on } \\
\text { sexual drive }\end{array}$ & $\begin{array}{l}\text { Sthreepriyopabhoga } \\
\text { PreetiPramadasu } \\
\text { Harshabahulam } \\
\text { Apatyabahulam } \\
\text { Chyavanam }\end{array}$ & $\begin{array}{l}\text { Libido } \\
\text { Exhilaration } \\
\text { Erection and ejaculation }\end{array}$ & $\begin{array}{l}\text { Oestrogen can enhance sexual drive } \\
\text { in female. }\end{array}$ \\
\hline \multicolumn{4}{|c|}{ Influence of hormone on morphology } \\
\hline $\begin{array}{l}\text { Effect } \\
\text { Bone an } \\
\text { teeth }\end{array}$ & $\begin{array}{l}\text { Samsamhataasthi } \\
\text { Snigdhavruttasara } \\
\text { Sama samhata shi- } \\
\text { khara dasana }\end{array}$ & $\begin{array}{l}\text { Helps in bone mineralization } \\
\text { Helps in formation of bone matrix } \\
\text { Deposition of calcium in bone } \\
\text { Early fusion of epiphyses of long }\end{array}$ & Increase osteoblastic activity \\
\hline
\end{tabular}




\begin{tabular}{|c|c|c|c|}
\hline & & bones with shaft & \\
\hline $\begin{array}{l}\text { Effect on } \\
\text { Muscular } \\
\text { system }\end{array}$ & $\begin{array}{l}\text { Dehabalam } \\
\text { Dehaupacayam }\end{array}$ & $\begin{array}{l}\text { Act as anabolic hormone and increase } \\
\text { the muscle bulk } \\
\text { Also cause nitrogen retention in body } \\
\text { (positive nitrogen balance) } \\
\text { Muscle mass increases by about } 50 \% \text {, } \\
\text { after puberty }\end{array}$ & $\begin{array}{l}\text { Act as anabolic hormone and in- } \\
\text { crease the muscle bulk } \\
\text { Also cause nitrogen retention in body } \\
\text { (positive nitrogen balance) }\end{array}$ \\
\hline $\begin{array}{l}\text { Changes in } \\
\text { pelvic bone }\end{array}$ & Mahasphik & $\begin{array}{l}\text { Lengthening of pelvis } \\
\text { Funnel-like shape of pelvis. }\end{array}$ & $\begin{array}{l}\text { Subcutaneous fat deposition in hip, } \\
\text { breast, buttock } \\
\text { Broadening of pelvis with increased } \\
\text { transverse diameter }\end{array}$ \\
\hline \multicolumn{4}{|c|}{ Influence of hormone on psyche } \\
\hline \begin{tabular}{l|l} 
Aggressive- & $S$ \\
ness & 1 \\
& 1
\end{tabular} & $\begin{array}{l}\text { Soumya in Shukra- } \\
\text { Dhatu sarata, } \\
\text { Dhairyam }\end{array}$ & Yes & Empathy etc. emotions \\
\hline \multicolumn{4}{|c|}{ Influence of hormone on physiology } \\
\hline Voice & $\begin{array}{l}\text { Prasanna swara } \\
\text { Snigdha swara }\end{array}$ & $\begin{array}{l}\text { Bass masculine voice } \\
\text { Hypertrophy of laryngeal muscles, } \\
\text { Enlargement and lengthening of } \\
\text { larynx, Thickening of vocal cords. }\end{array}$ & $\begin{array}{l}\text { Larynx in prepubertal stage } \\
\text { High pitched voice }\end{array}$ \\
\hline Skin & $\begin{array}{l}\text { Prasanna varna } \\
\text { Snigdha varna }\end{array}$ & $\begin{array}{l}\text { Thickness and ruggedness of sub- } \\
\text { cutaneous tissue } \\
\text { Deposition of proteins in skin } \\
\text { Increases the quantity of melanin } \\
\text { pigment } \\
\text { Enhances the secretory activity of } \\
\text { sebaceous glands }\end{array}$ & $\begin{array}{l}\text { Skin becomes soft and smooth. } \\
\text { Vascularity of skin also increases }\end{array}$ \\
\hline BMR & $\begin{array}{l}\text { DehaUpachayam, } \\
\text { Utsaham }\end{array}$ & $\begin{array}{l}\text { Increases the basal metabolic rate } \\
\text { to about } 5 \% \text { to } 10 \% \\
\text { Anabolic effects on protein metab- } \\
\text { olism. }\end{array}$ & $\begin{array}{l}\text { Increases the whole-body metabo- } \\
\text { lism slightly } \\
1 / 3^{\text {rd }} \text { increase as caused by male sex } \\
\text { hormone }\end{array}$ \\
\hline $\begin{array}{l}\text { Haemopoietic } \\
\text { system }\end{array}$ & $\begin{array}{l}\text { Pandutvam in } \\
\text { Shukrakshaya. } \\
\text { Bhrajishnuta in Shukra } \\
\text { sara }\end{array}$ & $\begin{array}{l}\text { Testosterone can enhance erythro- } \\
\text { poiesis } \\
\text { Increases the blood volume by in- } \\
\text { creasing the water retention and } \\
\text { ECF volume }\end{array}$ & Vasodilation \\
\hline $\begin{array}{l}\text { Secondary } \\
\text { sexual charac- } \\
\text { ters like hair } \\
\text { growth }\end{array}$ & $\begin{array}{l}\text { Balanamapi vaya: } \\
\text { parinamat Shukra } \\
\text { pradurbhavanti } \\
\text { Romarajyadaya- } \\
\text { nareenam }\end{array}$ & $\begin{array}{l}\text { At the onset of puberty, } \\
\text { Causes male type of hair distribu- } \\
\text { tion on the body } \\
\text { Hair growth over the pubis, along } \\
\text { linea alba up to umbilicus, on face, } \\
\text { chest and other parts of the body } \\
\text { such as back and limbs }\end{array}$ & $\begin{array}{l}\text { At the onset of puberty, } \\
\text { Hair develops in the pubic region } \\
\text { and axilla. } \\
\text { Body hair growth is less. } \\
\text { Scalp hair grows profusely }\end{array}$ \\
\hline
\end{tabular}

Few other references show that Shukra can also be correlated to semen along with sperm. The secretion of Shukra during the copulation (Sthree purusha samyoga) and the shudha Shukra lakshanas like the consistency of Shukra prove the same. Existence of Shukra throughout the entire body and its predomi- 
nance decide the gender exemplifies that it could be sex chromosome too. Sthree Shukra concept can be understood as sex hormones in female which are involved in the general metabolic functions and the Bartholin gland secretion too.

\section{CONCLUSION}

Human being has seven Dhatu. Even though all these Dhatu have specific locations in the body, but they are present in subtle form in each cell. In the same way, every cell has a part of Shukra Dhatu, as every cell is replicated by mitosis and meiosis. It can function as an anabolic hormone; along with contributes to reproduction. On broad aspect, stem cells which have the self-renewal and reproduction ability can be taken as Shukra Dhatu. Focusing on reproductive physiology, it could be sex hormones, seminal secretions along with sperm and sex chromosomes.

\section{REFERENCES}

1. Astangahrudaya by Vagbhata, Saravangasundara commentary by Arunadatta, Ayurveda rasayana commentary by Hemadri, edited by Hari Sastri, Reprinted 2017, Varanasi, Choukhambha Orientalia, sutra sthana, $11^{\text {th }}$ chapter, verse 1 , page 182

2. Charak Samhita of Agnivesh by Charak \& Dridhabala, Charak Samhita with Ayurveda Dipika Commentary by Chakrapanidatta, edited by Jadavji Trikamji Acharya Reprinted 2005, Varanasi, Chaukhamba Surbharati Prakashan, Nidanasthan, $6^{\text {th }}$ Chapter, 19, Page 220

3. SariraKria Vidnanam, A textbook of physiology Part 2 by Dr Nandini Dileep Dhargalkar, Choukhambha Sanskrit Series office, Varanasi, $2^{\text {nd }}$ edition, chapter 13, page 523

4. Amarakosha of Amarasimha, with the commentary of Bhanuji Dikshita, edited by Pandit shivadas, $6^{\text {th }}$ chapter, $2^{\text {nd }}$ pada, verse 62

5. Charak Samhita of Agnivesh by Charak \& Dridhabala, Charak Samhita with Ayurveda Dipika Commentary by Chakrapanidatta, edited by Jadavji Trikamji Acharya Reprinted 2005, Varanasi, Chaukhamba Surbharati Prakashan, Sareerasthan, $2^{\text {nd }}$ Chapter, 3-4 verse, Page 302

6. Acharya Sushrut, Sushrut Samhita with Nibandhsangraha Commentary by Dalhan and NyaychandrikakhyaPanjika by Gayadasa, edited by Jadavji Trikamji Acharya Reprinted 2004, Varanasi, Chaukhamba
Krishnadasa Academy, Sutrasthana $15^{\text {th }}$ Chapter verse 5,Page 67

7. Acharya Sushrut, Sushrut Samhita with Nibandhsangraha Commentary by Dalhan and NyaychandrikakhyaPanjika by Gayadasa, edited by JadavjiTrikamji Acharya Reprinted 2004, Varanasi, Chaukhamba Krishnadasa Academy, Sutrasthana $15^{\text {th }}$ Chapter verse 7, Page 67-68

8. Acharya Sushrut, Sushrut Samhita with Nibandhsangraha Commentary by Dalhan and Nyaychandrikakhya Panjika by Gayadasa, edited by JadavjiTrikamji Acharya Reprinted 2004, Varanasi, Chaukhamba Krishnadasa Academy, Sutras Thana $15^{\text {th }}$ Chapter verse 7, Page 67-68

9. Acharya Sushrut, Sushrut Samhita with Nibandhsangraha Commentary by Dalhan and Nyaychandrikakhya Panjika by Gayadasa, edited by Jadavji Trikamji Acharya Reprinted 2004, Varanasi, Chaukhamba Krishnadasa Academy, Sutrasthana $15^{\text {th }}$ Chapter verse 7, Page 67-68

10. Acharya Sushrut, Sushrut Samhita with Nibandhsangraha Commentary by Dalhan and Nyaychandrikakhya Panjika by Gayadasa, edited by Jadavji Trikamji Acharya Reprinted 2004, Varanasi, Chaukhamba Krishnadasa Academy, Sutrasthana $15^{\text {th }}$ Chapter verse 7, Page 67-68

11. Acharya Sushrut, Sushrut Samhita with Nibandhsangraha Commentary by Dalhan and NyaychandrikakhyaPanjika by Gayadasa, edited by Jadavji Trikamji Acharya Reprinted 2004, Varanasi, Chaukhamba Krishnadasa Academy, Sutrasthana $15^{\text {th }}$ Chapter verse 7,Page 67-68

12. Charak Samhita of Agnivesh elaborated by Charak \& Dridhabala, Charak Samhita with Ayurveda Dipika Commentary by Chakrapanidatta, edited by Jadavji Trikamji Acharya Reprinted 2005, Varanasi, Chaukhamba Surbharati Prakashan, chikitsasthan $2^{\text {nd }}$ chapter ( $4^{\text {th }}$ pada), verse 39 , page 397

13. Charak Samhita of Agnivesh elaborated by Charak \& Dridhabala, Charak Samhita with Ayurveda Dipika Commentary by Chakrapanidatta, edited by Jadavji Trikamji Acharya Reprinted 2005, Varanasi, Chaukhamba Surbharati Prakashan, chikitsasthan $2^{\text {nd }}$ chapter ( $4^{\text {th }}$ pada), verse 45 , page 396

14. Acharya Sushrut, Sushrut Samhita with Nibandhsangraha Commentary by Dalhan and NyaychandrikakhyaPanjika by Gayadasa, edited by Jadavji Trikamji Acharya Reprinted 2004, Varanasi, Chaukhamba 
Krishnadasa Academy, Sareerasthana $4^{\text {th }}$ Chapter verse 20-21,Page 357

15. Acharya Sushrut, Sushrut Samhita with Nibandhsangraha Commentary by Dalhan and Nyaychandrikakhya Panjika by Gayadasa, edited by JadavjiTrikamji Acharya Reprinted 2004, Varanasi, Chaukhamba Krishnadasa Academy, Sareerasthana $10^{\text {th }}$ Chapter verse 42,Page 391

16. Charak Samhita of Agnivesh by Charak \& Dridhabala, Charak Samhita with Ayurveda Dipika Commentary by Chakrapanidatta, edited by JadavjiTrikamji Acharya Reprinted 2005, Varanasi, ChaukhambaSurbharatiPrakashan, Vimana sthan, $5^{\text {th }}$ chapter, verse 8 , page 251

17. Astanga Samgraha by Vagbhata, commentary by Kasiraj Atridev Gupta, Chaukhambha Krishna das Academy, Varanasi, Sareerasthana $6^{\text {th }}$ chapter, Verse43, Page 311

18. Acharya Sushrut, Sushrut Samhita with Nibandhsangraha Commentary by Dalhan and Nyaychandrikakhya Panjika by Gayadasa, edited by JadavjiTrikamji Acharya Reprinted 2004, Varanasi, Chaukhamba Krishnadasa Academy, Sutra sthana 14th Chapter, verse 10,Page 60

19. Charak Samhita of Agnivesh by Charak\&Dridhabala, Charak Samhita with Ayurveda Dipika Commentary by Chakrapanidatta, edited by Jadavji Trikamji Acharya Reprinted 2005, Varanasi, Chaukhamba Surbharati Prakashan, chikitsasthan $15^{\text {th }}$ chapter, verse 33-35, page 515

20. Astangahrudaya by Vagbhata, saravangasundara commentary by Arunadatta, Ayurveda rasayana commentary by Hemadri, edited by Hari Sastri, Reprinted 2017, Varanasi, Choukhambhaorientalia, sareera sthana, $3^{\text {rd }}$ chapter, verse 65, page 399

21. Acharya Sushrut, Sushrut Samhita with Nibandhsangraha Commentary by Dalhan and Nyaychandrikakhya Panjika by Gayadasa, edited by JadavjiTrikamji Acharya Reprinted 2004, Varanasi, Chaukhamba Krishnadasa Academy, Sutrasthana $14^{\text {th }}$ Chapter verse 10, Page 60

22. Acharya Sushrut, Sushrut Samhita with Nibandhsangraha Commentary by Dalhan and Nyaychandrikakhya Panjika by Gayadasa, edited by Jadavji Trikamji Acharya Reprinted 2004, Varanasi, Chaukhamba Krishnadasa Academy, Sareerasthana $10^{\text {th }}$ Chapter verse 42, Page 391

23. Madava Nidana of Madhukosa, commentary by Vijayarakshita and Sreekantadatta $3^{\text {rd }}$ chapter, verse 16 , page 208
24. Sembulingam. K, Male reproductive system. In: Essentials of, Medical Physiology, 6th ed New Delhi, India, Jay Pee Brothers Medical Publishers;2013 p-493

25. Sembulingam. K, Erythropoiesis (Chapter 9). In: Essentials of, Medical Physiology, 6th ed New Delhi,India ,Jay Pee Brothers Medical Publishers;2013 p73

26. Indu Khurana, Male reproductive physiology, In Medical physiology for undergraduates, New Delhi, India, Elseveir; 2013, p-641

27. Charak Samhita of Agnivesh by Charak \& Dridhabala, Charak Samhita with Ayurveda Dipika Commentary by Chakrapanidatta, edited by Jadavji Trikamji Acharya Reprinted 2005, Varanasi, Chaukhamba Surbharati Prakashan, chikitsasthan $15^{\text {th }}$ chapter, verse $33-35$, page 515

28. Indu Khurana, Male reproductive physiology, In Medical physiology for undergraduates, New Delhi, India, Elseveir; 2013, p-641

29. Acharya Sushrut, Sushrut Samhita with Nibandhsangraha Commentary by Dalhan and Nyaychandrikakhya Panjika by Gayadasa, edited by Jadavji Trikamji Acharya Reprinted 2004, Varanasi, Chaukhamba Krishnadasa Academy, Sareerasthana $3^{\text {rd }}$ Chapter, verse 5, Page 351

30. Charak Samhita of Agnivesh elaborated by Charak \& Dridhabala, Charak Samhita with Ayurveda Dipika Commentary by Chakrapanidatta, edited by Jadavji Trikamji Acharya Reprinted 2005, Varanasi, Chaukhamba Surbharati Prakashan, chikitsasthansthan $2^{\text {nd }}$ chapter ( $4^{\text {th }}$ pada), verse 39 , page 396

31. Astanga Samgraha by Vagbhata, commentary by Kasiraj Atridev Gupta, Chaukhambha Krishna das Academy, Varanasi, Sareera sthana1, Verse 72, Page 271

32. Acharya Sushrut, Sushrut Samhita with Nibandhsangraha Commentary by Dalhan and Nyaychandrikakhya Panjika by Gayadasa, edited by Jadavji Trikamji Acharya Reprinted 2004, Varanasi, Chaukhamba Krishnadasa Academy, Sareerasthana $2^{\text {nd }}$ Chapter verse 47, Page 349

33. Acharya Sushrut, Sushrut Samhita with Nibandhsangraha Commentary by Dalhan and Nyaychandrikakhya Panjika by Gayadasa, edited by JadavjiTrikamji Acharya Reprinted 2004, Varanasi, Chaukhamba Krishnadasa Academy, Sutra sthana 14th Chapter, verse 18,Page 63

34. Acharya Sushrut, Sushrut Samhita with Nibandhsangraha Commentary by Dalhan and Nyaychandrikakhya 
Panjika by Gayadasa, edited by Jadavji Trikamji Acharya Reprinted 2004, Varanasi, Chaukhamba Krishnadasa Academy, Sutra sthana 14th Chapter, verse 15,Page 63

35. Charak Samhita of Agnivesh elaborated by Charak \& Dridhabala, Charak Samhita with Ayurveda Dipika Commentary by Chakrapanidatta, edited by Jadavji Trikamji Acharya Reprinted 2005, Varanasi, Chaukhamba Surbharati Prakashan, chikitsasthan $2^{\text {nd }}$ chapter ( $4^{\text {th }}$ pada), verse41-43,page 396

36. Roger D Stanworth, Thigh, Testosterone for the ageing in male; Current evidence and recommended practice:In Clinic interv Ageing.2008 Mar 3(1):25-44

37. Acharya Sushrut, Sushrut Samhita with Nibandhsangraha Commentary by Dalhan and Nyaychandrikakhya Panjika by Gayadasa, edited by Jadavji Trikamji Acharya Reprinted 2004, Varanasi, Chaukhamba Krishnadasa Academy, Sareerasthana $2^{\text {nd }}$ Chapter verse21, Page 345

38. Astangahrudaya by Vagbhata, saravangasundara commentary by Arunadatta, Ayurveda rasayana commentary by Hemadri, edited by Hari Sastri, Reprinted 2017, Varanasi, Choukhambhaorientalia, Sareera sthana, $1^{\text {st }}$ chapter, verse 17 ,page 365

39. Sembulingam. K, Male reproductive physiology, Seminal vesicle (chapter 72).In: Essentials of Medical Physiology, 6th ed New Delhi, India, Jay Pee Brothers Medical Publishers;2013 p-500

40. Sembulingam. K, Male reproductive physiology, Prostate (chapter 74). In: Essentials of Medical Physiology, 6th ed New Delhi, India ,Jay Pee Brothers Medical Publishers;2013 p-501

41. Sembulingam. K, Male reproductive physiology, Semen (chapter 73). In: Essentials of, Medical Physiology, 6th ed New Delhi, India, Jay Pee Brothers Medical Publishers;2013 p-503

42. Charak Samhita of Agnivesh elaborated by Charak \& Dridhabala, Charak Samhita with Ayurveda Dipika Commentary by Chakrapanidatta, edited by Jadavji Trikamji Acharya Reprinted 2005, Varanasi, Chaukhamba Surbharati Prakashan, vimana sthan $8^{\text {th }}$ chapter, verse 109 , page 278

43. Piera Versura\& Emilio C Campos (2005) Menopause and dry eye. A possible relationship, Gynecological Endocrinology, 20:5, 289298, DOI: $10.1080 / 09513590400027257$

44. Sembulingam. K, Male reproductive physiology, (chapter 74). In: Essentials of Medical Physiology, 6th ed New Delhi, India ,Jay Pee Brothers Medical Publishers;2013 p-462,478.

\section{Source of Support: Nil \\ Conflict of Interest: None Declared}

How to cite this URL: Resmy Raj. A \&C hitra. M. Gawande: A Conceptual Study To Understand The Physiological Perspective Of Shukra Dhatu. International Ayurvedic Medical Journal \{online\} 2020 \{cited July, 2020\} Available from:

http://www.iamj.in/posts/images/upload/3930 3938.pdf 